\title{
Development of Management Guidelines for a Disaster Mental Health Crisis Assistance Team using a Delphi Process
}

\author{
Sungeun You ${ }^{1 \dagger}$ Hwajeong Yu ${ }^{1} \quad$ Jong-Sun Lee ${ }^{2}$ Minyoung Sim ${ }^{3,4} \quad$ Myung-Soo Lee $^{5} \quad$ Jong-Woo Paik ${ }^{6}$ \\ Jeongyee $\mathrm{Bae}^{7}$ Soo Hyun Park ${ }^{8}$ Yun Kyeung Choi ${ }^{9}$
}

\begin{abstract}
${ }^{1}$ Department of Psychology, Chungbuk National University, Cheongju; ${ }^{2}$ Department of Psychology, Kangwon National University, Chuncheon; ${ }^{3}$ Department of Stress and Anxiety Disorder, National Center for Mental Health, Seoul; ${ }^{4}$ National Center for Trauma, National Center for Mental Health, Seoul; ${ }^{5}$ Yongin Mental Hospital, Yongin; ${ }^{6}$ Department of Psychiatry, Kyung Hee University College of Medicine, Seoul; ${ }^{7}$ Department of Nursing, Inje University, Busan; ${ }^{8}$ Department of Psychology, Yonsei University, Seoul; ${ }^{9}$ Department of Psychology, Keimyung University, Daegu, Korea
\end{abstract}

\begin{abstract}
Disaster mental health crisis assistance refers to a series of activities to promote psychosocial recovery of disaster survivors and the community affected by a disaster. Crisis assistance activities are performed at a team level, not at an individual level, and thus it is important to foster trained assistance teams in the community. Yet expert consensus regarding how to cultivate and provide such team training is lacking. The purpose of this study was to develop management guidelines for a Disaster Mental Health Crisis Assistance Team (DMH-CAT) using a Delphi process. In this study, an expert panel was conducted to develop initial items for management guidelines, subsequent to which two structured online surveys were administered to disaster mental health experts who had not participated in the initial item development. Through this process, 84 guidelines across 13 domains were derived. The subsections in the guideline included definition of terms, mission and goals, composition, roles of the team, team leader, and team members in preparation and acute disaster phases, respectively, assessment of team competency and operational systems, education and training, team care and prevention of burnout, and ethics. Overall the level of expert consensus for the final items was high, with a consensus mean of 8.20 on a scale of 1 to 9 . The management guidelines of the DMH-CAT developed in this study are composed of items describing general principles that are applicable to various forms of the DMH-CAT.
\end{abstract}

Keywords: DMH-CAT, disaster mental health, crisis assistance team, guidelines, Delphi

재난으로 인한 피해는 물리적, 경제적 피해에서부터 심리적 피해에 이르기까지 광범위하다. 이러한 재난의 특성 때문에 재난에 대한 대응도 인명구조작업에서부터 물리적 복구작업, 재난경험자들의 신체적, 정신적 회복을 위한 의료, 정신보건 서비스 제공 등, 다각적

\footnotetext{
${ }^{\dagger}$ Correspondence to Sungeun You, Department of Psychology, Chungbuk National University, 1 Chungdae-ro, Seowon-gu, Cheongju, Korea; E-mail: syou@chungbuk.ac.kr
}

Received Mar 04, 2018; Accepted Apr 08, 2018

This study was supported by a grant of the Korean Mental Health Technology R\&D Project, Ministry of Health \& Welfare, Republic of Korea (HM15C1189).
인 측면에서 이루어져야 한다. 특히 재난으로 인한 심리적 후유증 은 초기에 예방적 조치를 적절히 취하지 못하면 장기화될 수 있고, 심하면 정신과적 장애로 이어질 수도 있다(Goldmann \& Galea, 2014; Neria, Nandi, \& Galea, 2008; North \& Pfefferbaum, 2013). 재 난 발생 직후 재난경험자들의 심리적 고통을 줄이고 중장기적 심리 적 후유증을 감소시키기 위해서는 재난 발생 초기부터 현장에서 재난경험자들의 적절한 대처와 일상적 기능의 회복 과정을 돕는 정 신건강 위기지원이 필수적이며, 필요한 경우 전문기관에 의뢰하여 중장기 서비스를 받을 수 있도록 안내해야 한다(James, 2007; North \& Pfefferbaum, 2013). 이러한 정신건강 위기지원은 전문가 개인 차 
You et al.

원이 아닌 조직 차원에서 공인된 관련 기관에 소속된 사람들로 구 성된 팀 활동 형태로 제공되며, 이러한 팀은 지역 내외의 관련 단체, 행정공무원, 자원봉사자 등의 다양한 직역의 사람들과 함께 협력 적으로 일하는 것이 일반적이다.

재난 발생 시 제공되는 조직 차원의 팀 단위 재난정신건강 위기 지원은 일반적인 정신보건 분야에서 흔히 이루어지는 서비스 형태 가 아니어서 이를 위한 별도의 교육과 훈련, 팀 운영을 위한 지침이 필요하다. 재난 발생 시 시기별, 단계별로 적절한 대응이 무엇인지 에 대한 전문가들의 합치된 의견을 알아보기 위한 연구는 수행된 바 있으나(Bisson et al., 2010; Suzuki, Fukasawa, Nakajuma, Narisawa, \& Kim, 2012), 실제 재난정신건강 위기지원을 제공하는 팀을 어떻게 양성하고 운영해야 하는지에 대한 전문가들의 합치된 의견 을 검증한 경험적 연구는 국내외에 전무하다. 예를 들어, 외상스트 레스에 대한 유럽연합체(The European Network for Traumatic Stress, TENTS)의 지원으로 Bisson 등(2010)이 델파이 연구를 통해 개발한 '재난 후 심리사회적 지원에 대한 가이드라인(이하 TENTS 가이드라인)'에서는 재난 발생 시 제공되어야 할 심리사회적 지원 의 핵심적인 구성요소를 시기별, 단계별로 제시하고 있다. 하지만 이 가이드라인은 재난 발생 이전의 준비단계에서 해야 할 일들에 대한 가이드라인을 일부 포함하고 있을 뿐, 재난정신건강 팀이 어 떻게 운영되어야 하고 어떤 역할과 기능을 담당해야 하는지에 대한 가이드라인은 포함하고 있지 않다. 또한 유사한 델파이 연구가 일 본에서도 실시되었지만(Suziki et al., 2012) 역시 재난 이후 제공되 는 심리사회적 지원의 핵심적인 활동에 대한 내용이 주를 이루고 있고, 재난정신건강 팀의 운영과 역할 및 기능에 관한 내용은 포함 되어 있지 않다. 흥미로운 점은 Suziki 등(2012)의 델파이 연구에서 정신건강 전문가의 역할에 대한 문항들이 일부 포함되었지만 이 중 어느 것도 연구에서 설정한 전문가 의견 합치도 기준을 충족하지 못하였다는 점이다.

위에서 제시한 가이드라인 외에 경험적 연구를 통해 타당성이 검 증되지는 않았지만 기관별로 핵심적인 활동원칙이나 윤리 강령들 을 제시하고 있다. 인도적 지원기관 간 상임위원회(Inter-Agency Standing Committee, IASC)에서 출판한 '재난 시 정신건강 및 심 리사회적 지원에 대한 IASC 가이드라인(IASC, 2008)'이나 미국연 방재난관리청(FEMA)에서 제시하고 있는 재난정신건강 위기지원 의 핵심적인 원칙들과 윤리 강령 등이 대표적인 예라고 볼 수 있다. 하지만 역시 재난정신건강 위기지원을 위한 팀을 어떻게 운영해야 하는지에 대한 구체적인 가이드라인은 포함되어 있지 않다. 국립 피 해자 지원 기관(National Organization for Vitim Assistance, NOVA)에서는 위기대응팀 훈련매뉴얼(Young, 2009)을 통해
NOVA에서 운영하는 위기대응팀의 목표와 서비스 수준, 구성 및 역할 등에 대한 가이드라인을 간략하게 제공하고 있지만, 이는 이 동식 팀으로 구성되어 지역사회 위기 시 파견 자문 및 교육을 주로 담당하는 NOVA 위기지원팀의 특성에 맞게 만들어진 가이드라인 이어서 다양한 형태로 운영되고 있는 국내의 재난정신건강 위기지 원팀에는 적용하기 어려운 면이 있다.

국내의 대표적인 재난정신건강 위기지원팀으로는 보건복지부 산하 기관인 국립정신건강센터의 심리위기지원단, 경기도 광역정 신건강증진센터를 중심으로 구성된 Disaster Psychiatric Assistance Team(D-PAT), 국민안전처의 지원으로 대한적십자사에서 위탁 운영 중인 재난심리회복지원센터 등이 있다. 국립정신건강센 터 심리위기지원단과 D-PAT은 상시팀 형태로 조직이 구성되어 있 으나 평상시에는 팀 구성원들이 각자 다른 정신건강 업무를 담당하 고 재난이 발생하면 팀 활동이 가동되는 형태로 운영되고 있다. 한 편 시도별로 별도의 센터가 운영되고 있는 재난심리회복지원센터 는 평상시에도 자원봉사자 교육, 재난 발생 지역 추후 방문상담 등 의 재난업무를 담당하고 있지만 센터장과 실무자 1-2명 정도의 소 규모로 운영되고 있어 재난이 발생하면 자원봉사자들을 중심으로 지원활동을 수행한다. 이 외에도 심리학, 정신의학, 간호학, 사회복 지학 등의 관련 학문 분야의 학술단체에서도 크고 작은 조직이 위 원회 형식으로 구성되어 운영되고 있다. 또한 최근 국립정신건강센 터 내에 '국가트라우마센터(National Center for Trauma)'가 개소 하여(2018년 4월), 향후 국내 재난정신건강 위기지원과 관련된 연 구, 교육, 행정, 관련 기관 네트워크 등의 영역에서 중심적인 역할을 수행할 것으로 기대되고 있다.

이와 같이 현재 정부부처, 관련 학술단체, 민간단체 등을 중심으 로 다양한 형태의 재난정신건강 위기지원팀이 구성되어 운영되고 있지만 이러한 팀을 어떻게 운영하고 교육, 훈련해야 하는지에 대한 지침은 명확히 마련되어 있지 않다. 또한 지역마다 충분한 수의 인 력으로 구성된 상시팀을 운영하기 어려운 실정이어서 실제 대형 재 난이 발생하면 다양한 직역의 관련 단체 소속 구성원들이 참여하 는 연합팀이 임시로 구성되어 지원활동이 행해지는 경우가 많다. 이러한 경우 재난발생 지역의 지자체 기관, 중앙정부기관, 학술단 체, 민간단체 소속 구성원이 함께 팀을 꾸려 현장지원을 하게 된다. 예를 들어, 국내에서는 지난 2017년 포항 지진 이후 위에서 기술한 정부기관 및 학술단체 산하의 다학제 정신건강 전문가들이 국립부 곡병원 의료진과 함께 ‘포항 현장심리지원단’이라는 임시 연합팀을 구성하여 재난정신건강 위기지원을 제공하였다.

위에서 살펴본 바와 같이 재난정신건강 위기지원팀의 형태는 다 양하지만 이들의 미션과 목표, 요구되는 역량, 활동 내용, 윤리 강령 
등은 유사하다. 본 연구에서는 재난정신건강 위기지원을 수행하는 이러한 다양한 형태의 팀을 '재난정신건강 위기지원팀(Disaster Mental Health Crisis Assistance Team, DMH-CAT)'이라고 명명 하고 이러한 팀을 운영하는 데 필요한 일반적이고 보편적인 가이드 라인을 개발하는 것을 주요 목적으로 하였다. 본 연구는 국내 재난 정신건강 분야에서 실무, 교육, 자문, 연구 등의 수행 경험이 있는 다양한 분야의 전문가들을 대상으로 델파이 절차를 사용하여 가 이드라인을 개발하였다. 특히 상시팀과 수시팀 모두에 적용될 수 있는 일반적인 가이드라인이면서도 구체적이고 실질적인 내용을 포함하는 운영 가이드라인을 개발하는 것을 목적으로 하였다.

\section{방 법}

본 연구에서는 델파이(Delphi) 방법을 통해 재난정신건강 위기지 원팀(DMH-CAT) 운영 가이드라인을 개발하였다. 델파이 연구는 해결하고자 하는 문제에 대한 정보가 불충분할 때, 전문가들의 의 견 수집 및 반복적인 피드백 제공을 통한 체계적이고 구조화된 의 사소통 기법을 사용하여 전문가들의 합치된 의견을 도출하는 절 차이다(Boulkedid, Abdoul, Loustau, Sibony, \& Alberti, 2011; Linstone \& Turoff, 1975; Okili \& Pawlowski, 2004). 일반적으로 델파 이 절차에서는 선별된 익명의 전문가 집단에게 2 회기 이상의 구조 화된 설문을 통해 의견을 중재하고 타협할 수 있는 기회를 제공하 며, 회기는 전문가들의 의견이 합의에 도달할 때까지 시행된다. 구 체적으로, 각 회기마다 수집된 전문가들의 의견을 통계적으로 요 약하여 다음 회기 설문에 피드백으로 제공한다. 이러한 방식을 통 해 전문가들은 다른 전문가들의 의견과 자신의 견해를 비교하면서 서로의 의견을 조율해나가게 된다. 델파이 설문 결과 전문가들의 의견이 합치된 문항은 다음 회기 설문에서 제외되고, 의견이 합치 되지 않은 문항에 대해서는 설문을 재실시하게 된다. 기본적인 델 파이 절차는 모든 회기가 구조화된 설문 형식으로 진행되지만 대 부분의 델파이 연구에서는 회기 중 1 회기 정도를 오프라인 패널회 의를 삽입하는 수정된 형태의 델파이 절차를 사용하였다(Boulkedid et al., 2011).

본 연구에서는 초기문항 개발 단계에서 오프라인 전문가 패널을 시행하고, 그 다음 단계에서 익명의 전문가 집단을 대상으로 구조 화된 온라인 설문을 2 회 시행하였다. 이러한 방법을 채택한 이유는 델파이 연구에서 초기문항의 구성이 매우 중요한 요소인데, 재난정 신건강 위기지원팀의 운영 가이드라인은 모델이 될 만한 사전 정보 가 매우 부족하고 국내에 실제 운영되고 있는 상시팀도 일부에 불과 하여 관련 국내 전문가들의 의견이 최대한 반영된 초기문항을 구
Expert panel $(N=17)$

Developed 86 items across 13 domains

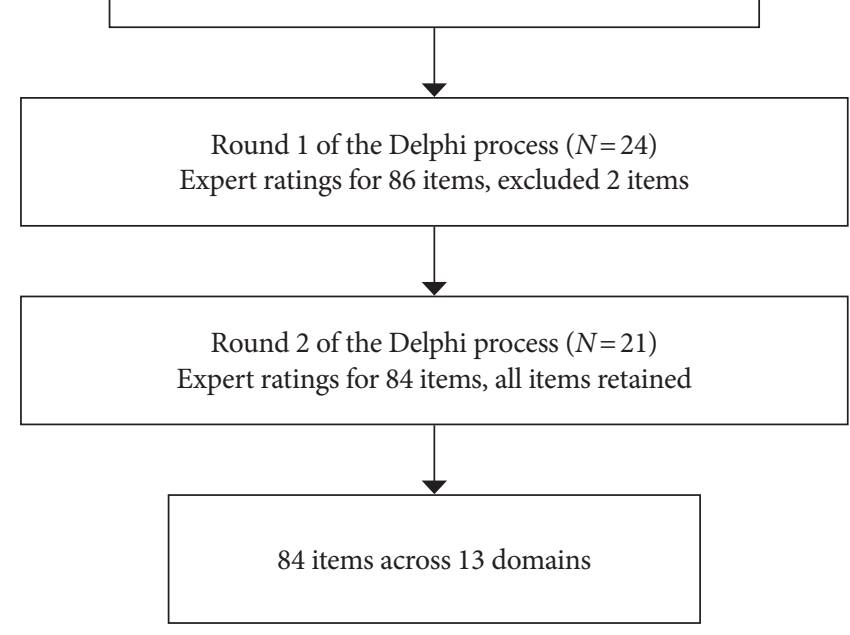

Figure 1. Flow chart of the Delphi process.

성할 필요가 있다고 판단했기 때문이다. 이에 기존의 델파이 연구 에서 전문가 패널을 델파이 설문 중간 회기에 주로 시행했던 것과 달리, 본 연구에서는 전문가 패널을 델파이 설문 이전 단계에서 시 행하고, 전문가 합치도는 구조화된 온라인 설문을 통해서만 검증 하였다. 본 연구의 절차를 Figure 1에 제시하였다. 본 연구는 충북대 학교 생명윤리심의위원회의 승인을 받은 후 진행되었다.

\section{문항개발 절차}

DMH-CAT 운영 가이드라인 초기 문항은 국내외 문헌 조사, 국내 재난정신건강 위기지원팀 운영지침, 국내 재난정신건강 위기지원 관련 실무 경험 및 연구·자문·교육 경험을 바탕으로 임상심리전문 가 3 인이 작성하였다. 총 10 개의 영역(개요, 미션과 목표, 팀의 구성, 팀의 역할과 기능, 팀 리더의 역할과 업무, 팀원의 역할과 업무, 팀 평가체계, 교육과 훈련, 팀 케어 및 지지, 윤리)에 대해 66개의 초기 문항이 제작되었다. 이 중 일부 문항은 국립정신건강센터 심리위기 지원단 운영규정(National Center for Mental Health, 2017)과 외상 스트레스에 대한 유럽 네트워크에서 개발한 'TENTS Guidelines (The European Network for Traumatic Stress; Bisson et al., 2010)' 에서 추출하였다. 윤리지침 두 문항은 재난정신건강지원을 위한 교 육프로그램 개발 및 인력양성 연구팀의 '인력양성 모델보고서 (Workforce Development and Training Program Development Team for Disaster Mental Health Support, 2016)'에서 추출하였다.

초기문항에 대한 검증 및 수정작업을 위해 다학제 전문가로 구 성된 전문가 패널 회의가 국립정신건강센터 회의실에서 개최되었 
You et al.

다(2017년 6월 9일). 전문가 패널에는 심리, 정신건강의학, 간호, 사 회복지, 비정부기구(NGO)에서 재난정신건강지원 관련 업무를 수 행하는 전문가 17 명이 초청되었다. 패널의 이질성 확보를 위해 대학 기관, 병원, 국립기관, 민간단체에 소속되어 있는 관련분야 연구자 와 실무자(팀장급 및 팀원급)를 모두 포함시켜 팀 운영에 필요한 전 문가 의견이 다양한 관점에서 수집될 수 있도록 하였다.

전문가 패널 회의에 초청된 17 명 중 11 명이 오프라인 회의에 참 석하였고, 오프라인 회의에 참석하지 못한 6 인에 대해서는 온라인 회의를 통해 의견을 수집하였다. 전문가 패널에 참석한 17 명은 전 문 분야별로 임상심리 6 명, 정신건강의학 4 명, 간호 4 명, 사회복지 1 명, 상담심리 분야 전문가 1 명과 비정부기구 $(\mathrm{NGO})$ 재난심리지원 팀장 1 명으로 구성되었다. 전문가 패널회의에서는 각 문항에 대해 적합 또는 부적합 여부를 판정하고 부적합하다고 판정하는 경우 부적합 사유와 수정의견을 구두 또는 서면으로 제출하도록 하였 다. 또한 가이드라인에 추가로 포함될 필요가 있는 문항에 대한 의 견을 구두 또는 서면으로 작성하여 제출하도록 하였다. 온라인으 로 패널에 참여하신 분들께는 오프라인 패널회의에서 사용되었던 동일한 회의 자료를 이메일로 보내드린 후 자문 의견을 이메일로 회 수하였다. 본 전문가 패널에 참여한 모든 분들에게는 소정의 자문 료가 제공되었다.

다음으로 전문가 패널에서 논의된 의견을 반영하여 가이드라인 초기문항을 수정, 보완하였다. 총 10 개의 영역 중 '팀의 역할과 기 능, '팀 리더의 역할과 업무', '팀원의 역할과 업무'를 평상시와 재난 - 위기 발생 시로 구분하는 것에 대한 의견이 패널회의에서 다수의 전문가에 의해 제기되어 이를 반영하였다. 또한 패널진으로부터 델 파이 절차를 통해 전문가 합의를 도출할 필요가 있다고 제안된 문 항들을 추가로 포함하였다. 이러한 과정을 통해 수정된 가이드라 인은 총 13 개 영역, 86 개 문항으로 구성되었다. 본 전문가 패널을 통 해 본 연구에서 개발한 운영 가이드라인을 적용할 주체를 재난정 신건강 위기지원팀(DMH-CAT)이라고 명명하기로 합의하였다(가

2.1 The DMH-CAT should clearly establish a team mission and goals and share them with team members.

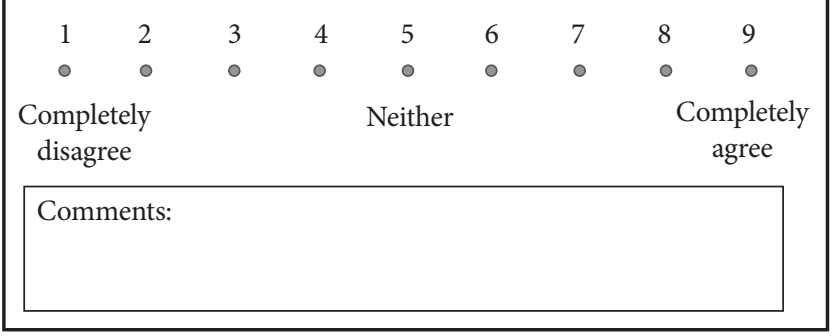

Figure 2. Example of a survey item in round one.
이드라인 1.1 과 1.2 참조).

\section{델파이 절차}

델파이 설문은 전문가 패널에 참여했던 분야별 전문가로부터 추천 받은 전문가 30 인을 대상으로 실시되었다. 추천된 30 인은 분야별로 정신건강의학 분야 전문가 7 명, 임상심리 5 명, 상담심리 3 명, 사회복 지 5명, 비정부기구 $(\mathrm{NGO})$ 재난정신건강 지원 담당자 5 명, 간호 4 명, 지역사회 심리학 1 명이 포함되었다. 문항개발 과정에 참여했던 연 구원과 전문가 패널진 17 명은 델파이 설문 대상에서 제외되었다. 1 차 설문(Round 1)은 2017년 8월 7일부터 22일까지 2주 동안 온라인 설문 형식으로 진행되었다. 추천된 30 인의 다학제 전문가에게 이메 일로 연구에 대한 안내와 함께 설문 링크가 발송되었고, 이 중 24 명 (응답률 $80 \%$ )이 1 차 델파이 설문을 완료하였다. 1 차 설문은 각 문 항에 대해 동의하는 정도를 1 (완전히 동의하지 않는다)에서 9(완전 히 동의한다)의 9점 리커트 형식으로 평정하게 하였고, 5 점 미만으 로 동의하지 않는 경우 그 이유를 서술하도록 하였다. 1 차 설문에서 사용된 문항의 예를 Figure 2에 제시하였다.

델파이 2차 설문(Round 2)은 2017년 12월 23일부터 2018년 1월 16 일까지 약 3 주 동안 시행되었다. 1 차 설문이 배포되었던 전문가와 동일한 30 인의 전문가에게 2 차 설문 링크가 이메일로 발송되었고, 이 중 21 명(응답률 $70 \%)$ 이 2 차 설문을 완료하였다. 2 차 설문은 1 차 설문 결과를 반영하여 수정된 문항이 발송되었고 각 문항별로 1 차 설문 결과가 함께 제시되었다. 구체적으로 1 차 설문 결과 도출된 문 항별 전문가 동의 평균(mean), 중앙값(median)과 1-9점 리커트 동 의평정에서 7점 이상 동의한 비율(\%)이 제시되었고, 해당하는 경우 1 차 설문에서 제출된 전문가 의견이 함께 제시되었다. 2 차 설문에 서 사용된 문항의 예를 Figure 3에 제시하였다.

4.2 The DMH-CAT should receive education and training on strengthening personal and team competency in relation to disaster psychological assistance in preparation for a disaster.

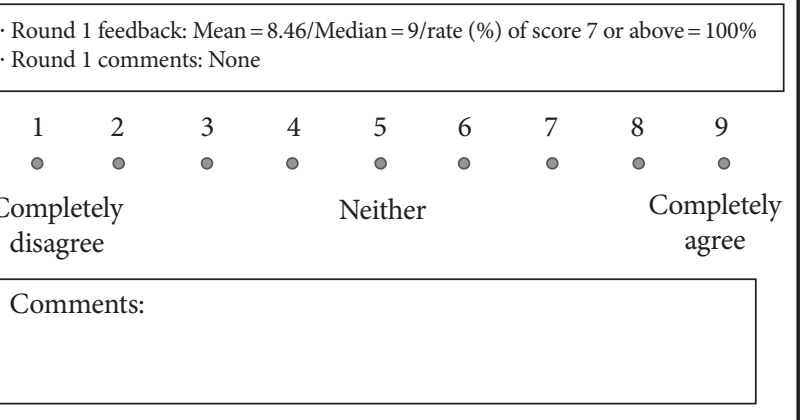

Figure 3. Example of a survey item in round two. 


\section{결 과}

\section{델파이 연구참여자 특성}

1 차 설문 응답률은 $80 \%$ (30명 중 24명), 2 차 설문 응답률은 $70 \%(30$ 명 중 21명)였고, Table 1에 제시된 바와 같이 연령, 성별, 전문 분야 의 비율 등 대부분의 인구통계학적 특성 및 재난정신건강 지원경험 이 1 차, 2 차 설문 참여자 간 유사하였다. 대부분의 참여자가 3 년 이 상의 재난정신건강 지원 경험(1차 $87.5 \%, 2$ 차 $85.7 \%), 3$ 회 이상의 재

Table 1. Sociodemographic Characteristics of Delphi Participants

\begin{tabular}{|c|c|c|c|c|}
\hline \multirow{2}{*}{ Variable } & \multicolumn{2}{|c|}{ Round $1(N=24)$} & \multicolumn{2}{|c|}{ Round $2(N=21)$} \\
\hline & $n$ & $\%$ & $n$ & $\%$ \\
\hline Age (Mean, $S D$ ) & 46.5 & 8.91 & 46.3 & 9.05 \\
\hline \multicolumn{5}{|l|}{ Gender } \\
\hline Male & 12 & 50 & 10 & 47.6 \\
\hline Female & 12 & 50 & 11 & 52.4 \\
\hline \multicolumn{5}{|l|}{ Professional Affiliation } \\
\hline Psychiatry & 6 & 25 & 5 & 23.8 \\
\hline Clinical psychology & 4 & 16.7 & 4 & 19.1 \\
\hline Counseling psychology & 2 & 8.3 & 2 & 9.5 \\
\hline Nursing & 3 & 12.5 & 2 & 9.5 \\
\hline Social work & 5 & 20.8 & 5 & 23.8 \\
\hline NGO & 3 & 12.5 & 2 & 9.5 \\
\hline Community psychology & 1 & 4.2 & 1 & 4.8 \\
\hline \multicolumn{5}{|c|}{ Years of experience in disaster mental health } \\
\hline Less than 1 year & 1 & 4.2 & 1 & 4.8 \\
\hline $1-3$ year & 2 & 8.3 & 2 & 9.5 \\
\hline More than 3 years & 21 & 87.5 & 18 & 85.7 \\
\hline \multicolumn{5}{|c|}{ Number of disaster mental health assistance } \\
\hline None & 0 & 0 & 0 & 0 \\
\hline $1-2$ times & 5 & 20.8 & 6 & 28.6 \\
\hline More than 3 times & 19 & 79.2 & 15 & 71.4 \\
\hline \multicolumn{5}{|c|}{ Disaster mental health related experience ${ }^{\mathrm{a}}$} \\
\hline Research & 17 & 70.8 & 18 & 85.7 \\
\hline Consultation & 17 & 70.8 & 17 & 81.0 \\
\hline $\begin{array}{l}\text { Educational course or } \\
\text { lecture }\end{array}$ & 16 & 66.7 & 18 & 85.7 \\
\hline $\begin{array}{l}\text { Direct field activities or } \\
\text { outreach }\end{array}$ & 12 & 50.0 & 16 & 76.2 \\
\hline $\begin{array}{l}\text { Indirect assistance } \\
\text { (development of } \\
\text { educational materials, } \\
\text { leaflet etc.) }\end{array}$ & 12 & 50.0 & 13 & 61.9 \\
\hline Individual counseling & 17 & 70.8 & 17 & 81.0 \\
\hline Group counseling & 11 & 45.8 & 11 & 52.4 \\
\hline Media coverage & 9 & 37.5 & 9 & 42.9 \\
\hline Served as a team leader & 9 & 37.5 & 10 & 47.6 \\
\hline Served as a team member & 8 & 33.3 & 8 & 38.1 \\
\hline
\end{tabular}

${ }^{a}$ Multiple responses were allowed.
난정신건강 지원 경험이 있다고 보고하였다(1차 79.2\%, 2차 71.4\%). 연구참여자들의 대다수가 재난정신건강과 관련 있는 연구, 자문, 강의, 개인상담 및 직접활동 경험이 있다고 보고하였고 이 외에도 간접적인 지원활동, 집단상담, 언론대응 경험 등이 있다고 보고하 였다. 팀의 리더로 재난정신건강 지원활동을 한 경험이 있다고 보 고한 경우는 1,2 차 각각 $37.5 \%, 47.6 \%$ 였고, 팀원으로 재난정신건강 지원활동 경험을 한 적이 있다고 보고한 경우는 1,2 차 각각 $33.3 \%$, $38.1 \%$ 였다(Table 1).

\section{델파이 1차 설문 결과}

본 연구에서는 유사한 선행연구(Bisson et al., 2010; Suzuki et al., 2012)에 기반하여 1-9점의 리커트 척도로 평정된 문항별 평정 평균 이 7점 이상 또는 7점 이상 동의율이 $70 \%$ 이상이면 전문가들의 합 의가 이루어졌다고 간주하였다. 1 차 설문 결과, 총 86 개 문항 중 위 의 기준에 부합하지 않았던 문항은 1 개도 없었으나, DMH-CAT 팀 원의 역할과 업무(평상시) 항목 중 '팀원은 재난인식개선 교육 및 캠페인을 실시한다'의 문항이 평정 평균 $(M) 7.08$, 중앙값 $(M d n) 7.0$, 7점 이상 동의율이 $62.5 \%$ 로 7점 이상 동의율이 70\%에 미치지 못하 였다. 그 다음으로 낮은 동의율을 보인 문항은 '팀원은 지역사회 자 원봉사자들을 교육, 양성한다'로 평정 평균 $(M) 7.13$, 중앙값 $(M d n)$ $8.0,7$ 점 이상 동의율이 $70.8 \%$ 였다. 이 두 문항에 동의하지 않는 이 유로는 이러한 팀원의 활동은 재난정신건강 위기지원팀이 속한 조 직의 운영방식에 따라 달라질 수 있다는 의견과 상시팀이 아닌 수 시팀인 경우 위의 활동은 팀원의 역할로 적절치 못하다는 의견이 보고되었다. 본 연구의 목적이 상시팀과 수시팀 모두에 일반적으로 적용될 수 있는 가이드라인을 개발하는 데 있다는 점을 고려하여 이 두 문항은 2 차 설문에서 제외되었다.

1 차 설문 결과 전체 86 개 문항에 대한 전문가 동의 평정 전체 평 균은 7.98(SD=.32)이었고 중앙값 평균은 $8.15(S D=.41)$ 였다. 전문 가들의 동의 평정 평균이 가장 높았던 항목은 'DMH-CAT 구성원 은 지원활동 시 알게 된 재난경험자들의 개인정보 및 사생활에 대 한 비밀을 유지하고 보호할 윤리적 의무가 있다 $(M=8.58, M d n=$ 9, 7점 이상 동의율 $=100 \%$ )'와 'DMH-CAT은 재난에 대비하여 평 상시에 재난심리지원과 관련하여 개인역량 강화 및 팀 역량 강화에 대한 교육과 훈련을 받아야 한다 $(M=8.46, M d n=9,7$ 점 이상 동의 율 $=100 \%$ )'였다(Table 2). 델파이 1 차 설문 결과, 전체 86 개 문항 중 50 개 문항(58.1\%)에서 전문가 $90 \%$ 이상이 1-9점 평정 척도에서 7 점 이상으로 평정하였다. 
You et al.

Table 2. Results of Delphi Rounds for DMH-CAT Management Guidelines

\begin{tabular}{|c|c|c|c|c|c|c|c|}
\hline \multirow{2}{*}{ Item } & & \multicolumn{3}{|c|}{ Round 1} & \multicolumn{3}{|c|}{ Round 2} \\
\hline & & $M$ & $M d n$ & $\geq 7(\%)$ & $M$ & $M d n$ & $\geq 7(\%)$ \\
\hline \multicolumn{8}{|c|}{ 1. Definition of terms } \\
\hline 1.1 & $\begin{array}{l}\text { "Disaster mental health crisis assistance" refers to a series of activities to alleviate psycho- } \\
\text { logical distress, promote emotional stability, and prevent psychological sequelae of disas- } \\
\text { ter survivors, and to identify high-risk groups in the early stage and connect them with } \\
\text { appropriate services, and thus ultimately promote overall recovery of disaster survivors } \\
\text { and the community affected by disasters. }\end{array}$ & 8.13 & 8.5 & 91.7 & 8.57 & 9 & 100.0 \\
\hline 1.2 . & $\begin{array}{l}\text { Disaster Mental Health Crisis Assistance Team (DMH-CAT) refers to a team that was cre- } \\
\text { ated with the goal of providing crisis assistance, as defined in guideline 1.1. }\end{array}$ & 7.79 & 8 & 83.3 & 8.19 & 8 & 95.2 \\
\hline 1.3 . & $\begin{array}{l}\text { "Disaster survivors" refer to individuals who have directly experienced a disaster, their } \\
\text { families, bereaved families, and witnesses. Individuals exposed to a disaster by participat- } \\
\text { ing in activities such as rescue, restoration, and volunteer services in times of disasters are } \\
\text { also included as targets of service. }{ }^{\dagger}\end{array}$ & 7.96 & 8 & 87.5 & 8.14 & 8 & 95.2 \\
\hline 1.4. & $\begin{array}{l}\text { The DMH-CAT determines assistance when a disaster or crisis occurs by discussing the } \\
\text { need of mental health assistance, appropriate timing, length, and methods of such assis- } \\
\text { tance. The DMH-CAT also consults with relevant organizations to conduct service activi- } \\
\text { ties when there are external requests. }\end{array}$ & 7.96 & 8 & 91.7 & 8.05 & 8 & 95.2 \\
\hline \multicolumn{8}{|c|}{ 2. Mission and goals of the DMH-CAT } \\
\hline 2.1. & $\begin{array}{l}\text { The DMH-CAT should clearly establish a team mission and goals and share them with } \\
\text { team members. }\end{array}$ & 8.38 & 9 & 91.7 & 8.62 & 9 & 100.0 \\
\hline 2.2 . & $\begin{array}{l}\text { The mission of the DMH-CAT is to set the lives and safety of disaster survivors as its ut- } \\
\text { most priority and to help alleviate their distress and promote their recovery in a humani- } \\
\text { tarian manner while also respecting their human rights. }\end{array}$ & 8.33 & 8.5 & 95.8 & 8.38 & 8 & 100.0 \\
\hline 2.3. & $\begin{array}{l}\text { The usual operating objective of the DMH-CAT is to cultivate personal and team compe- } \\
\text { tency for efficient disaster mental health assistance. }\end{array}$ & 7.46 & 8 & 79.2 & 7.76 & 8 & 95.2 \\
\hline 2.4 . & $\begin{array}{l}\text { The goal of the DMH-CAT during disasters/crises is to provide prompt and effective psy- } \\
\text { chological assistance and psychological first aid activities for minimizing and resolving } \\
\text { the psychological damage of disaster survivors. }\end{array}$ & 7.83 & 8 & 83.3 & 8.14 & 8 & 95.2 \\
\hline 2.5 . & $\begin{array}{l}\text { The detailed goals of the DMH-CAT should be established with team leaders and team } \\
\text { members, and all team members should have a clear understanding of the goals. }\end{array}$ & 8.13 & 8.5 & 87.5 & 8.29 & 9 & 95.2 \\
\hline \multicolumn{8}{|c|}{ 3. Composition of the DMH-CAT } \\
\hline 3.1. & $\begin{array}{l}\text { The DMH-CAT should be composed of specialists in the mental health field. Mental } \\
\text { health specialists include professionals in the fields of psychiatry, psychology, nursing, } \\
\text { and social welfare, for example. }\end{array}$ & 7.42 & 8 & 79.2 & 7.62 & 8 & 76.2 \\
\hline 3.2 . & $\begin{array}{l}\text { In addition to mental health specialists, administrative personnel, volunteers, and legal } \\
\text { consultants may also be included in the DMH-CAT. }\end{array}$ & 7.67 & 8 & 87.5 & 7.29 & 8 & 76.2 \\
\hline 3.3. & The DMH-CAT may be composed of, and operated as, permanent or on-demand teams. & 7.75 & 8 & 87.5 & 7.67 & 8 & 85.7 \\
\hline 3.4 . & $\begin{array}{l}\text { There may be various team structures for providing onsite services based on the type and } \\
\text { degree of damage. The DMH-CAT conducts its services as part of the field operation or- } \\
\text { ganization and work collaboratively with various experts. }\end{array}$ & 8.13 & 8 & 95.8 & 8.33 & 8 & 95.2 \\
\hline \multicolumn{8}{|c|}{ 4. Role and function of the DMH-CAT (In routine situations) } \\
\hline 4.1 . & $\begin{array}{l}\text { The DMH-CAT must not only understand the disaster response organization system that } \\
\text { is needed to carry out disaster mental health crisis assistance in communities, but also } \\
\text { identify the obtainable human and material resources in the community and must have a } \\
\text { pre-existing working liaison with organizations capable of providing such resources. }\end{array}$ & 8.42 & 8.5 & 95.8 & 8.52 & 9 & 100.0 \\
\hline 4.2 . & $\begin{array}{l}\text { The DMH-CAT should receive education and training on strengthening personal and } \\
\text { team competency in relation to disaster psychological assistance in preparation for a di- } \\
\text { saster. }\end{array}$ & 8.46 & 9 & 100.0 & 8.62 & 9 & 100.0 \\
\hline 4.3. & The DMH-CAT must have a team evaluation system in place. & 8.21 & 8.5 & 95.8 & 8.38 & 9 & 100.0 \\
\hline 4.4 . & $\begin{array}{l}\text { The DMH-CAT may operate a hotline when necessary, and operation guidelines should be } \\
\text { prepared to this end. }\end{array}$ & 7.88 & 8 & 87.5 & 8.33 & 8 & 100.0 \\
\hline 4.5 . & $\begin{array}{l}\text { The DMH-CAT may be deployed to support affected areas in need of help when neces- } \\
\text { sary. }\end{array}$ & 7.83 & 8 & 91.7 & 8.29 & 8 & 95.2 \\
\hline
\end{tabular}


Table 2. Continued

\begin{tabular}{|c|c|c|c|c|c|c|c|}
\hline \multirow{2}{*}{ Item } & & \multicolumn{3}{|c|}{ Round 1} & \multicolumn{3}{|c|}{ Round 2} \\
\hline & & $M$ & $M d n$ & $\geq 7(\%)$ & $M$ & $M d n$ & $\geq 7(\%)$ \\
\hline 4.6. & $\begin{array}{l}\text { The DMH-CAT must cooperate with regular training systems when necessary (e.g., Disas- } \\
\text { ter Response Korean training) and promote collaboration with disaster assistance sys- } \\
\text { tems. }\end{array}$ & 7.96 & 8 & 87.5 & 8.33 & 8 & 100.0 \\
\hline \multicolumn{8}{|c|}{ 5. Role and function of the DMH-CAT (In disaster/crisis situations) } \\
\hline 5.1. & $\begin{array}{l}\text { The DMH-CAT will build a unified response system through collaboration or cooperation } \\
\text { with the disaster response system during disaster situations and establish plans for men- } \\
\text { tal health crisis support. }\end{array}$ & 8.17 & 8.5 & 87.5 & 8.24 & 8 & 100.0 \\
\hline 5.2 . & The DMH-CAT will provide psychological first aid in the acute stage of a disaster. & 8.04 & 8 & 87.5 & 8.43 & 8 & 100.0 \\
\hline 5.3. & $\begin{array}{l}\text { The mental health specialists of the DMH-CAT will conduct training regarding psycholog- } \\
\text { ical first aid and ethics and support activities for volunteers in disaster situations and pro- } \\
\text { vide consultation on assistance activities. }\end{array}$ & 7.63 & 8 & 83.3 & 8.33 & 8 & 100.0 \\
\hline 5.4 . & $\begin{array}{l}\text { The DMH-CAT will provide information such as disaster response and coping, psychiatric } \\
\text { and psychosocial assessment and screening of high-risk groups, acute stress counseling, } \\
\text { and stabilization programs during disaster situations. }\end{array}$ & 8.00 & 8 & 91.7 & 8.24 & 8 & 100.0 \\
\hline 5.5 . & $\begin{array}{l}\text { The DMH-CAT will refer individuals affected by disaster to appropriate professional treat- } \\
\text { ment facilities or relevant organizations when necessary. }\end{array}$ & 8.17 & 8 & 95.8 & 8.10 & 8 & 90.5 \\
\hline 5.6. & $\begin{array}{l}\text { The DMH-CAT will compile and distribute a media guideline so that survivors are not re- } \\
\text { exposed to trauma through the media during disaster situations and place a person in } \\
\text { charge of media response in order to build a consistent media response system. }\end{array}$ & 7.67 & 8 & 83.3 & 7.86 & 8 & 90.5 \\
\hline 5.7. & $\begin{array}{l}\text { The DMH-CAT may request assistance from external community specialists when neces- } \\
\text { sary. }\end{array}$ & 8.42 & 8 & 100.0 & 8.29 & 8 & 100.0 \\
\hline \multicolumn{8}{|c|}{ 6. Role and task of DMH-CAT leaders (In routine situations) } \\
\hline 6.1. & $\begin{array}{l}\text { DMH-CAT leaders will provide opportunities for team members to communicate and } \\
\text { strengthen teamwork by holding regular meetings. }\end{array}$ & 8.17 & 8 & 91.7 & 8.19 & 8 & 100.0 \\
\hline 6.2 . & $\begin{array}{l}\text { DMH-CAT leaders will construct team goals and an evaluation system through discus- } \\
\text { sions with team members. }\end{array}$ & 8.04 & 8 & 95.8 & 8.33 & 8 & 100.0 \\
\hline 6.3 . & $\begin{array}{l}\text { DMH-CAT leaders must be knowledgeable about the community's human and material } \\
\text { resources needed for carrying out community disaster mental health crisis assistance and } \\
\text { assume the role of person-in-charge of overseeing communication with work-connected } \\
\text { agencies. }\end{array}$ & 8.17 & 8 & 95.8 & 8.33 & 8 & 100.0 \\
\hline 6.4 . & $\begin{array}{l}\text { DMH-CAT leaders will construct an emergency communication network in order to acti- } \\
\text { vate the response system depending on severity of a disaster/crisis. }\end{array}$ & 8.42 & 9 & 95.8 & 8.48 & 9 & 100.0 \\
\hline \multicolumn{8}{|c|}{ 7. Role and task of DMH-CAT leaders (In disaster/crisis situations) } \\
\hline 7.1. & $\begin{array}{l}\text { DMH-CAT leaders will establish team activity plans for disaster mental health crisis assis- } \\
\text { tance in disaster situations and direct and manage team tasks. }\end{array}$ & 8.08 & 8 & 91.7 & 8.29 & 8 & 100.0 \\
\hline 7.2 . & $\begin{array}{l}\text { DMH-CAT leaders will carry out decision-making on important matters related to team } \\
\text { activities. }^{\dagger}\end{array}$ & 7.42 & 8 & 75.0 & 7.52 & 8 & 85.7 \\
\hline 7.3. & $\begin{array}{l}\text { DMH-CAT leaders will allocate roles and tasks to team members based on their knowl- } \\
\text { edge and experience of team members' expertise. }\end{array}$ & 7.79 & 8 & 91.7 & 7.67 & 8 & 85.7 \\
\hline 7.4. & DMH-CAT leaders must supervise and provide feedback on the tasks of team members. & 7.83 & 8 & 87.5 & 7.95 & 8 & 95.2 \\
\hline 7.5 . & $\begin{array}{l}\text { DMH-CAT leaders will monitor for signs of exhaustion or vicarious trauma in team mem- } \\
\text { bers in consideration of the nature of the disaster situation and intervene when necessary. }\end{array}$ & 8.08 & 8 & 95.8 & 8.19 & 8 & 95.2 \\
\hline 7.6. & $\begin{array}{l}\text { DMH-CAT leaders will communicate with external agencies/organizations and assume the } \\
\text { role of building cooperative and collaborative relationships. }\end{array}$ & 7.96 & 8 & 91.7 & 8.24 & 8 & 100.0 \\
\hline 7.7. & $\begin{array}{l}\text { DMH-CAT leaders will hold regular meetings to encourage and communicate with team } \\
\text { members during crisis situations through which an emergency delivery system can be } \\
\text { built. }\end{array}$ & 8.08 & 8 & 87.5 & 7.95 & 8 & 95.2 \\
\hline 7.8. & $\begin{array}{l}\text { DMH-CAT leaders will hold assessment briefing meetings with team members who have } \\
\text { completed their duties in crisis situations to provide opportunities to process their re- } \\
\text { sponse experience and plan for effective assistance system. }\end{array}$ & 8.25 & 8 & 95.8 & 8.33 & 8 & 100.0 \\
\hline 7.9 . & $\begin{array}{l}\text { DMH-CAT leaders will make efforts to promote teamwork and manage conflict between } \\
\text { team members. }{ }^{\dagger}\end{array}$ & 7.67 & 8 & 79.2 & 8.14 & 8 & 100.0 \\
\hline
\end{tabular}


You et al.

Table 2. Continued

\begin{tabular}{|c|c|c|c|c|c|c|c|}
\hline \multirow{2}{*}{ Item } & & \multicolumn{3}{|c|}{ Round 1} & \multicolumn{3}{|c|}{ Round 2} \\
\hline & & $M$ & $M d n$ & $\geq 7(\%)$ & $M$ & $M d n$ & $\geq 7(\%)$ \\
\hline 7.10. & $\begin{array}{l}\text { DMH-CAT leaders will make efforts to secure the safety of team members during crisis } \\
\text { situations. }\end{array}$ & 8.21 & 9 & 87.5 & 8.48 & 9 & 100.0 \\
\hline
\end{tabular}

8. Role and task of DMH-CAT members (In routine situations)

8.1. Team members must be fully aware of their individual expertise and roles, have mutual re- $\begin{array}{rlllll}8.25 & 8.5 & 91.7 & 8.14 & 8 & 100.0\end{array}$ spect for the expertise of team members, and have a mutual understanding of their individual tasks. 8.2. Team members must be well-informed of administrative procedures and reporting sys- 8.08
tems.

Team members will train and cultivate community volunteers. ${ }^{\dagger}$

Team members will run disaster awareness improvement training and campaigns. ${ }^{\dagger \dagger}$

8.3. Team members must support the recovery support group meetings of disaster survivors.

8.4. Team members in charge of the press must be well-informed of ethics and conduct guide- 8.00 lines related to media response and act accordingly.

9. Role and task of DMH-CAT members (In disaster/crisis situations)

9.1. Team members must divide up disaster mental health assistance tasks and administrative 7.38 support tasks.

9.2. Team members must cooperate and communicate with each other to carry out tasks effi- 8.0 ciently. When necessary, team members must transfer tasks to maintain continuity of service for disaster survivors.

9.3. Team members must have a clear awareness of their roles and limitations in crisis situa- 8.21 tions and carry out their tasks within their legal rights and competence. 9.4. Team members must be flexible in responding to situations based on the administrative 8.08
procedures and reporting systems during crises.

9.5. Team members must record the nature of their support activities and complete and store 7.96 administrative documents.

9.6. Team members must take appropriate measures such as assessment and intervention for 7.67 high-risk groups (e.g., suicide crisis).

9.7. Team members must refrain from direct media contact/response to prevent misreporting 7.96 and release of personal opinions.

9.8. Team members must prioritize the team's objectives and fulfill followership in accordance 7.92 with the leader's line of command.

10. Assessment of team competency and operational system

10.1. DMH-CAT must conduct regular organizational assessment of team competency and op- 7.92
erations.

10.2. Consistent and systematic evaluation criteria and method must be arranged.

7.96 10.3. Internal evaluations must take place regularly, and evaluation periods and criteria must be 8.08
clearly provided.

10.4. Objective evaluations by external experts in addition to internal evaluations are needed. 7.29

10.5. DMH-CAT must create evaluation criteria that match project objectives. ${ }^{\dagger} \quad 8.00$

10.6. Team competency evaluations must be conducted regularly using an objective assessment 7.46 tool.

10.7. Assessment of factors that promote or disrupt team efficiency is needed.

10.8. Evaluation of team leadership is needed.

10.9. Evaluation on team following is needed.

10.10. Evaluation on team communication type is needed.

10.11. Team evaluation based on exchange of feedback between team members is needed. $\quad 7.79$

10.12. Education and training must be conducted in order to strengthen necessary competency 8.17 based on competency evaluation results.

$\begin{array}{rrrrrr}7.83 & 8 & 91.7 & 8.14 & 8 & 95.2 \\ 7.96 & 8 & 95.8 & 8.19 & 8 & 100.0 \\ 7.79 & 8 & 87.5 & 7.95 & 8 & 95.2 \\ 7.83 & 8 & 91.7 & 8.00 & 8 & 95.2 \\ 7.79 & 8 & 91.7 & 8.05 & 8 & 95.2 \\ 8.17 & 8 & 100.0 & 8.52 & 9 & 95.2\end{array}$


Table 2. Continued

\begin{tabular}{|c|c|c|c|c|c|c|c|}
\hline \multirow{2}{*}{ Item } & & \multicolumn{3}{|c|}{ Round 1} & \multicolumn{3}{|c|}{ Round 2} \\
\hline & & $M$ & $M d n$ & $\geq 7(\%)$ & $M$ & $M d n$ & $\geq 7(\%)$ \\
\hline \multicolumn{8}{|c|}{ 11. Education and training } \\
\hline 11.1. & $\begin{array}{l}\text { The public and private organizations that run DMH-CAT must draw up a budget for the } \\
\text { education and training of team members. }\end{array}$ & 8.33 & 9 & 95.8 & 8.48 & 9 & 100.0 \\
\hline 11.2. & $\begin{array}{l}\text { DMH-CAT members must receive regular education and training to advance their person- } \\
\text { al expertise and competency in empirical evidence-based disaster mental health crisis as- } \\
\text { sistance. }\end{array}$ & 8.33 & 8.5 & 95.8 & 8.43 & 9 & 100.0 \\
\hline 11.3. & $\begin{array}{l}\text { DMH-CAT members must receive regular education and training to advance team compe- } \\
\text { tency in efficient disaster mental health crisis assistance. }\end{array}$ & 8.33 & 8 & 95.8 & 8.38 & 9 & 100.0 \\
\hline 11.4. & $\begin{array}{l}\text { DMH-CAT members must receive regular education and training to advance their under- } \\
\text { standing of policies, laws, and systems related to disaster assistance. }\end{array}$ & 8.17 & 8 & 95.8 & 8.29 & 8 & 100.0 \\
\hline 11.5. & $\begin{array}{l}\text { DMH-CAT members must receive education concerning human rights protection and } \\
\text { ethics in disaster situations. }\end{array}$ & 8.33 & 9 & 95.8 & 8.38 & 8 & 95.2 \\
\hline 11.6. & DMH-CAT members must complete media response education. & 7.83 & 8 & 87.5 & 8.10 & 8 & 95.2 \\
\hline 11.7. & $\begin{array}{l}\text { DMH-CAT members must conduct simulation training in virtual crisis situations based } \\
\text { on previously prepared response plans. }\end{array}$ & 8.21 & 8 & 95.8 & 8.43 & 8 & 100.0 \\
\hline 11.8. & $\begin{array}{l}\text { During disasters/crises, DMH-CAT members must be placed in the field only after becom- } \\
\text { ing well-informed through prior education and activity guidelines pertaining to nature of } \\
\text { the disaster and field characteristics. }\end{array}$ & 8.25 & 8 & 95.8 & 8.38 & 8 & 100.0 \\
\hline 11.9. & $\begin{array}{l}\text { DMH-CAT members must receive consultation and/or supervision on response and inter- } \\
\text { vention following their participation in field assistance. }\end{array}$ & 8.17 & 8 & 95.8 & 8.38 & 8 & 100.0 \\
\hline 11.10. & $\begin{array}{l}\text { Necessary education and training must be received before participating in onsite disaster } \\
\text { assistance activities. }{ }^{\dagger}\end{array}$ & 7.63 & 8 & 87.5 & 8.24 & 8 & 95.2 \\
\hline \multicolumn{8}{|c|}{ 12. Team care and burnout prevention } \\
\hline 12.1. & $\begin{array}{l}\text { The public and private organizations running DMH-CAT must provide a budget for oper- } \\
\text { ating members' team care and burnout prevention programs. }\end{array}$ & 8.33 & 8.5 & 100.0 & 8.52 & 9 & 95.2 \\
\hline 12.2 . & Burnout prevention programs for DMH-CAT members must be run regularly. & 8.29 & 8 & 95.8 & 8.38 & 8 & 100.0 \\
\hline 12.3. & Team care and burnout prevention programs must be run following disaster intervention. & 8.33 & 8.5 & 95.8 & 8.57 & 9 & 100.0 \\
\hline 12.4. & $\begin{array}{l}\text { DMH-CAT must regularly provide programs for promoting teamwork (e.g., team-building } \\
\text { programs). }\end{array}$ & 8.04 & 8 & 87.5 & 8.00 & 8 & 90.5 \\
\hline 12.5. & $\begin{array}{l}\text { Welfare programs for DMH-CAT members (e.g., accident insurance, holiday/break sys- } \\
\text { tem) must be run based on personnel policy within the organization. }\end{array}$ & 8.08 & 8 & 91.7 & 7.62 & 8 & 90.5 \\
\hline 12.6. & $\begin{array}{l}\text { DMH-CAT members' personal interest and training in self-care is required. In addition, } \\
\text { team members have the duty to report their own physical and mental risks to the team } \\
\text { leader and ask for assistance. }\end{array}$ & 8.17 & 8 & 95.8 & 8.24 & 8 & 100.0 \\
\hline \multicolumn{8}{|c|}{ 13. Ethics } \\
\hline 13.1. & $\begin{array}{l}\text { The DMH-CAT must provide humanitarian support and possess elementary knowledge } \\
\text { regarding the need to respect not only the life and safety of individuals affected by disas- } \\
\text { ters but also their dignity and spiritual aspects. }\end{array}$ & 8.29 & 9 & 95.8 & 8.38 & 8 & 100.0 \\
\hline 13.2. & $\begin{array}{l}\text { The DMH-CAT must conduct assistance activities within the scope of team members' } \\
\text { training and education and carry out assistance tasks based on the recognition of the } \\
\text { clear limitations of what the team can and cannot do. }\end{array}$ & 8.38 & 9 & 100.0 & 8.62 & 9 & 100.0 \\
\hline 13.3. & $\begin{array}{l}\text { DMH-CAT members have the ethical duty to maintain confidentiality and protect person- } \\
\text { al information and privacy of disaster survivors they come to know during assistance ac- } \\
\text { tivities. }\end{array}$ & 8.58 & 9 & 100.0 & 8.76 & 9 & 100.0 \\
\hline 13.4. & $\begin{array}{l}\text { Disaster mental health assistance personnel must not conduct inhumane and unethical } \\
\text { personal research in disaster situations. }\end{array}$ & 7.21 & 8 & 75.0 & 7.90 & 8 & 90.5 \\
\hline Overall & Mean & 7.98 & 8.15 & 90.0 & 8.20 & 8.25 & 96.0 \\
\hline
\end{tabular}

${ }^{\dagger}$ Revised items in round two based on expert comments in round one. ${ }^{\dagger \dagger}$ Removed items in round two based on the 1 st round results. 
You et al.

\section{델파이 2차 설문 결과}

델파이 2 차 설문은 1 차 설문 문항 중 2 개 문항이 제외된 84 개 문항 에 대한 전문가 평정을 위해 실시되었다. 2 차 설문 결과도 1 차 설문 과 동일하게 문항별 평정 평균 7점 이상 또는 7점 이상 동의율 70\% 이상을 기준으로 전문가 의견 합치도 여부를 판정하였다. 분석 결 과, 84 개 문항 모두 위의 기준을 충족하는 것으로 나타났다(Table 2). 전체 84 개 문항에 대한 전체 평균은 $8.20(S D=.29)$ 이었고 중앙값 평균은 8.25(SD=.44)였다. 전문가들의 의견 수렴이 가장 높았던 문 항은 'DMH-CAT 구성원은 지원활동 시 알게 된 재난경험자들의 개인정보 및 사생활에 대한 비밀을 유지하고 보호할 윤리적 의무가 있다 $(M=8.76)$ ', 'DMH-CAT은 재난에 대비하여 평상시에 재난심 리지원과 관련하여 개인역량 강화 및 팀 역량 강화에 대한 교육과 훈련을 받아야 한다 $(M=8.62)$ ', 'DMH-CAT은 팀의 미션과 목표를 명확히 설정하고 이를 팀원들과 공유해야 한다 $(M=8.62)$ ', ' $\mathrm{DMH}-$ CAT은 팀원들이 받은 훈련과 교육의 범위 내에서 지원 활동을 해 야 하며, 팀이 할 수 있는 것과 할 수 없는 부분에 대한 명확한 한계 를 인식하고 이에 따른 지원 업무를 수행해야 한다 $(M=8.62)^{\prime}$ 순으 로 나타났다(Table 2). 델파이 2차 설문 결과, 전체 84 개 문항 중 77 개 문항(91.7\%)에서 전문가 $90 \%$ 이상이 1-9점 평정 척도에서 7점 이상으로 평정하였다. 1 차와 2 차 설문에서 84 개 문항에 대한 동의 평정평균과 7점 이상 평정 변화추이를 Figure 4에 제시하였다.

\section{논 의}

본 연구에서는 가이드라인 1.1에 제시한 재난정신건강 위기지원을 위해 만들어진 팀을 재난정신건강 위기지원팀(DMH-CAT)이라고 지칭하고 이러한 팀을 운영하는 데 필요한 가이드라인을 개발하였
다. 특히 국내 현황에 맞는 실질적인 가이드라인 개발을 위해 국내 재난정신건강 분야에서 실무, 교육, 연구, 자문 등의 업무 수행을 담 당하는 여러 분야의 전문가들을 대상으로 전문가 의견 수렴을 위 한 델파이 연구를 실시하였다. 본 연구에서는 전문가 패널을 통해 초기 문항을 개발하고 이에 대한 전문가 의견 합치도를 알아보기 위한 2 회기의 구조화된 델파이 설문을 실시하였다. 이러한 과정을 통해 총 13 개 영역에서 84 개의 가이드라인이 추출되었다.

먼저 본 연구에서 개발한 가이드라인의 개요 부분에서는 재난정 신건강 위기지원의 정의 및 이러한 지원을 수행하는 팀(i.e., DMH$\mathrm{CAT}$ )과 서비스를 받는 대상에 대한 정의 등에 대한 전문가들의 합 치된 견해가 기술되었다. 다음으로 DMH-CAT의 구성, 역할, 평가, 교육과 훈련, 팀 케어 및 소진예방을 위한 가이드라인이 제시되었 고, 마지막으로 재난정신건강 위기지원을 수행하는 데 있어 지켜야 할 윤리 지침이 제시되었다. 구체적으로 본 연구에서 개발한 DMH-CAT 운영 가이드라인은 용어의 정의, DMH-CAT의 미션 과 목표, DMH-CAT의 구성, DMH-CAT의 역할과 기능(평상시), DMH-CAT의 역할과 기능(재난·위기 발생 시), DMH-CAT 리더 의 역할과 업무(평상시), DMH-CAT 리더의 역할과 업무(재난·위 기 발생 시), DMH-CAT 팀원의 역할과 업무(평상시), DMH-CAT 팀원의 역할과 업무(재난·위기 발생 시), 팀 역량 및 운영체계에 대 한 평가, 교육과 훈련, 팀 케어 및 소진예방, 윤리의 13 개 영역으로 구성되었다.

\section{전문가 의견 수렴이 높았던 문항}

본 연구결과 도출된 가이드라인 대부분의 문항에서 평정 평균과 중앙값이 모두 최대 9점에 8점 이상으로 높게 나타나 높은 전문가 의견 합치도를 보였다. 전문가 의견 수렴이 가장 높았던 문항은 지
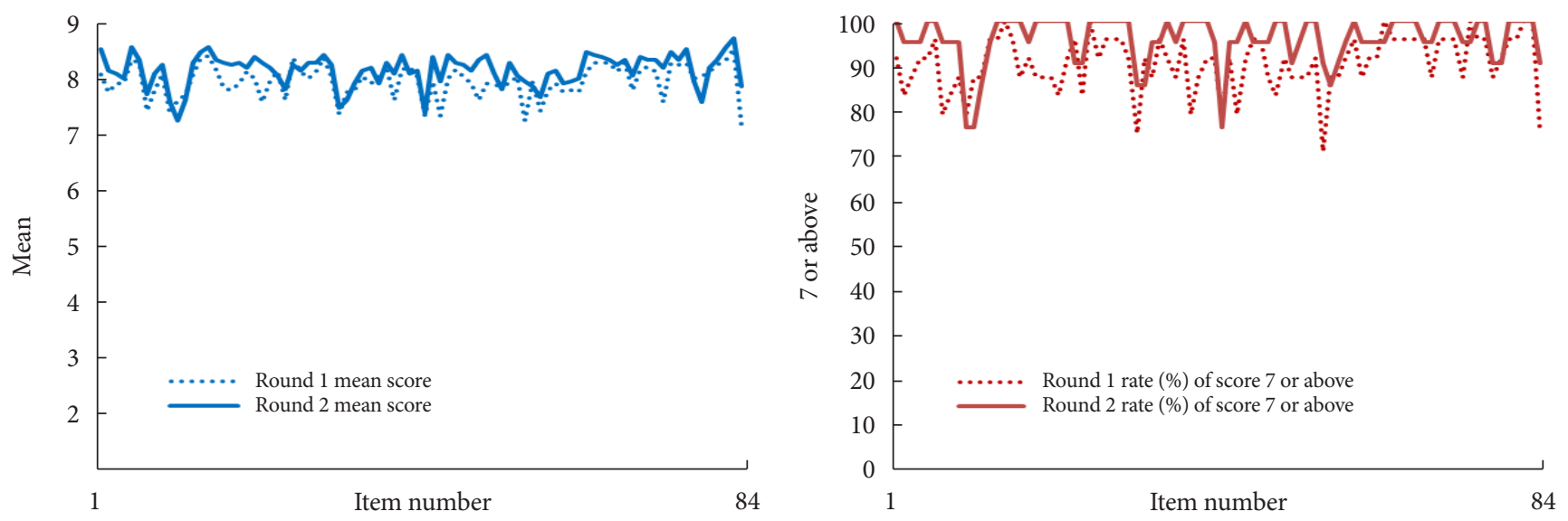

Figure 4. Changes in mean scores and rate (\%) of score 7 or above for the 84 items between rounds one and two. 
원활동 시 재난경험자의 개인정보 및 사생활에 대한 비밀을 유지하 고 보호할 윤리적 의무가 있다(가이드라인 13.3), 팀원들이 받은 교 육과 훈련의 범위 내에서 지원 활동을 해야 하며, 팀이 할 수 있는 것과 할 수 없는 부분에 대한 명확한 한계를 인식해야 한다(가이드 라인 13.2), 개인역량 강화 및 팀 역량 강화에 대한 교육과 훈련을 받아야 한다(가이드라인 4.2), 팀의 미션과 목표를 명확히 설정하 고 이를 팀원들과 공유해야 한다(가이드라인 2.1) 순이었다. 더불어 팀의 소진예방 프로그램에 대한 필요성(가이드라인 12.1과 12.3)과 평상시 준비활동(가이드라인 4.1과 6.4)에 관한 문항들도 높은 동 의율을 보였다.

이와 같은 결과는 국내 재난정신건강 분야의 전문가들이 재난정 신건강 위기지원 활동에 대한 명확한 미션과 목표를 설정하고 이를 팀이 공유하는 것과 윤리적이고 전문적인 지원 활동을 제공하는 것을 중요하게 여기고 있음을 시사한다. 윤리적이고 전문적인 지원 활동을 위해서는 평상시의 교육과 훈련을 통한 준비가 중요하다. 본 가이드라인에서는 이를 위해 교육과 훈련에 대한 가이드라인을 제시하였고, 특히 개인역량 증진을 위한 교육뿐 아니라 팀 역량 강 화를 위한 교육과 훈련의 필요성을 명시하였다. 또한 평상시 지역사 회 인적, 물적 자원에 대한 파악, 관련 기관과의 연계체계 마련, 비 상연락망 구축 등의 사전 준비활동과 소진예방 프로그램 운영 등 에 관한 가이드라인을 제시하였다.

중요한 결과 중 하나는 '재난정신건강 위기지원'의 정의(가이드 라인 1.1)에 대한 전문가 합치도가 높게 나타난 점이다. 이는 본 연 구에 참여한 전문가 다수가 ‘재난정신건강 위기지원'에 대한 공통 의 정의를 갖고 있었다는 점에서 그 의의가 있다. 본 연구에서 명명 하고 있는 재난정신건강 위기지원팀(DMH-CAT)은 가이드라인 1.1 에 제시된 재난정신건강 위기지원 활동을 위해 형성된 팀이라고 정의하였고, 현재 국내에서 다양한 명칭으로 구축, 운영되고 있는 재난정신건강 위기지원팀들이 일반적으로 참고할 수 있는 운영 가 이드라인을 개발하고자 하였다.

\section{전문가 의견 수렴이 낮았던 문항}

상대적으로 전문가 의견 수렴이 낮게 나타난 문항들은 팀의 구성, 리더 또는 팀원의 역할과 업무과 관련된 문항들이었다. 1 차 설문 결 과 낮은 동의율과 반대 의견에 근거하여 제거된 두 개의 문항은 '팀 원은 재난인식개선 교육 및 캠페인을 실시한다’와 '팀원은 지역사 회 자원봉사자들을 교육, 양성한다’로 이 두 문항은 모두 팀원의 평 상시 역할과 업무에 관한 문항이었다. 2 차 설문에서도 '팀원은 재난 경험자들의 회복 모임을 지원한다'가 낮은 동의율을 보여, $\mathrm{DMH}-$ CAT 팀원의 평상시 역할과 업무의 범위에 대한 의견이 다소 불일
치하는 경향을 보였다. 이에 대한 이유로 DMH-CAT이 상시팀인지 수시팀인지에 따라 팀원의 역할이 달라질 것이라는 의견이 제기되 었고 인식개선 캠페인, 자원봉사자 교육 및 양성, 회복 지지 모임 지 원 등의 업무는 상시팀일 경우에만 가능할 것이라는 의견과 상시팀 일 경우에도 팀원이 평상시에 재난 외의 다른 업무를 수행하는 국 내 재난정신건강 위기지원팀의 현황이 잘 반영되지 못한 가이드라 인이라는 의견이 제기되었다.

DMH-CAT의 구성과 리더의 역할 및 업무와 관련된 문항 중 일 부도 상대적으로 낮은 동의율을 보였다. 본 연구에서 개발한 가이 드라인에서는 DMH-CAT의 구성에서 상시팀 또는 수시팀으로 구 성될 수 있다고 제시하였으나 수시팀의 운영에 대한 회의적인 견해 가 제기되었다. 이에 대한 이유로 '위기 시에 상시의 경험이 바탕이 되어야 하기 때문에’라는 의견과 ‘수시팀은 책임감과 성실성이 떨어 질 것 같다'는 의견이 제기되었다. 하지만 지역사회에 상시팀이 존재 한다고 해도 대규모 재난의 경우 지역사회 자체의 인력만으로 정신 건강 위기지원을 감당하기 어려운 경우가 발생하고, 이때에는 다른 지역 또는 민간 단체에서 인력 지원을 받아야 한다. 이러한 경우 특 정 재난에 대한 임시 팀이 꾸려지게 되기 때문에 평상시에 팀워크 가 형성되어 있지 않은 다지역, 다학제 인력이 함께 재난에 대응해 야 하는 상황이 발생한다. 본 가이드라인은 이러한 국내 현실을 반 영하여 DMH-CAT이 상시팀과 수시팀으로 구성될 수 있다는 가정 하에 가이드라인을 개발하였다. 물론 특정 재난에 대한 대응을 위 해 임시로 꾸려지는 수시팀도 평상시에 교육과 훈련을 받은 사람들 로 구성되어야 한다는 가이드라인은 동일하게 적용되어야 한다.

리더의 역할에 대한 의견도 상황에 따라 운영 팀의 리더가 바뀔 수 있다는 측면에서 그 역할과 업무의 범위가 다소 명확하지 않다 는 견해가 제기되었다. 예를 들어, 재난 발생 시 현실적으로 의사결 정 주체가 지자체의 장이나 정부기관의 장이 되기 때문에 리더의 주체가 모호하다는 의견과 경우에 따라 재난이 발생한 지역의 정 신건강 전문가들과 협의하여 적절한 역할 분담을 제시하여야 한다 는 의견이 제안되었다. 물론 재난의 규모와 특성에 따라, 지역의 상 시팀이 주체가 될 수도 있고 특정 재난 대응을 위해 다른 지역의 인 력과 함께 임시로 형성된 수시팀이 주체가 될 수도 있다. 어떠한 경 우가 되든 재난·위기 시에 재난정신건강 위기지원을 위한 팀의 리 더는 결정되어야 하며, 리더는 가이드라인에 제시된 바와 같이 외 부기관과 의사소통하며 팀 활동을 계획하고 업무를 적절히 배분하 며 전체 업무를 총괄, 관리해야 한다.

소수이지만 전문가들의 상반된 의견이 제기된 문항으로 ' $\mathrm{DMH}$ CAT 구성원을 위한 복지프로그램(예: 상해보험, 휴가제도 등)은 조 직 내에서 인사규정에 따라 운영해야 한다(가이드라인 12.5)'가 있 
You et al.

었다. 팀 케어 및 소진 예방에 대한 가이드라인 중 복지체계에 대한 항목과 관련해서 복지혜택은 조직 내의 위치, 조직 특성, 채용 조건 에 따라 상이하여 일부 팀원들은 혜택을 받지 못할 우려가 있다는 문제가 제기되었고, 이에 대한 의무요건을 제시할 필요가 있다는 의견이 제출되었다. 또한 팀 케어 및 소진 예방과 관련하여 소진프 로그램에 대한 예산을 책정하고 프로그램을 운영하는 것보다 소진 예방을 위한 합리적인 업무할당 시스템이 더욱 중요하다는 의견이 있었다. 관련하여 현재 대부분의 재난정신건강 지원 업무가 기존의 다른 업무를 담당하고 있는 정신보건 기관에 부가적으로 할당되어 정신건강 지원 인력들이 과중한 업무를 수행해야 하는 시스템적인 문제점에 대한 지적도 제기되었다. 재난현장에서 정신건강 위기지 원을 수행하는 경우, 대리 외상 등의 심리적 고통을 경험할 위험이 있는데 이에 대한 조직 차원의 복지 혜택이나 보호망이 구축될 필 요가 있을 것으로 보인다. 정부기관 소속 구성원인 경우에는 소속 기관의 규정에 따라 받을 수 있는 복지 혜택이 있지만 민간 차원에 서 단기적으로 활동하는 자원봉사 인력의 경우 이러한 복지체계가 거의 마련되어 있지 않을 가능성이 있다.

마지막으로 '재난정신건강지원 인력은 재난 현장에서 비인도적 이고 비윤리적인 개인적 연구활동을 하지 않아야 한다(가이드라 인 13.4'는 항목에 대해서는 연구가 주된 목적이 될 수 있다는 견해 도 있었던 반면, 개인 연구만이 아니라 어떠한 형태의 연구라도 재 난 현장에서 실시되는 것은 비윤리적이라는 견해도 제기되어 양극 단의 의견이 존재하는 것으로 나타났다. 재난 시 정신건강 및 심리 사회적 지원에 관한 IASC 가이드라인(IASC, 2008)에서는 재난현 장 지원에 있어 핵심적인 원칙으로 인권과 형평성을 증진시킬 것과 해를 끼치지 않을 것을 명시하고 있다. 구체적으로, 재난현장에서 하지 말아야 할 행동 목록으로 '반복적으로 평가를 실시하거나 예 비 자료를 무비판적인 태도로 수용하지 않는다,' '해당 지역사회 또 는 위기상황에 처한 맥락에서 타당화되지 않은 평가 도구를 사용 하지 않는다, '후속 지원을 제공하지 않으면서 정신적 고통을 유발 하는 질문을 하지 않는다,' '정신장애 판정을 받은 사람들을 위한 적절하고 접근 가능한 서비스를 갖추고 있지 않은 상황에서 정신 장애 여부를 판단하기 위한 선별검사를 실시하지 않는다' 등을 명 시하고 있다. 이러한 가이드라인은 재난으로 인해 고통받고 있는 사람들의 인권을 존중하고 연구를 수행함으로써 발생할 수 있는 잠재적 해를 방지하기 위한 지침이라고 할 수 있다.

\section{결론 및 제언}

본 연구에서는 델파이 절차를 사용하여 13 개 영역, 총 84 개의 재난
정신건강 위기지원팀(DMH-CAT)의 운영 가이드라인을 개발하였 다. 본 연구에서 개발한 가이드라인은 국내에서 재난정신건강 위기 지원을 위해 형성된 다양한 형태의 팀을 운영하는 데 사용될 수 있 을 것으로 기대한다. 본 연구에서는 특정 재난 상황에 국한되지 않 는 가능한 일반적이고 보편적인 가이드라인을 개발하고자 하였다. 재난정신건강 위기지원을 제공하는 주체가 다양하고 동일한 조직/ 팀 내에서도 맡은 역할과 위치에 따라 DMH-CAT 운영에 필요한 요소에 대한 입장이 다를 수 있을 것이라는 가정하에 가능하면 다 양한 직역, 역할을 담당하는 전문가들을 포함하여 연구를 실시하 였다. 본 연구에 참여한 전문가들이 비교적 이질적인 사람들로 구 성되어 있었음에도 불구하고 최종 가이드라인에 대한 합치도 수준 은 상당히 높게 나타났다.

본 연구 결과 도출된 가이드라인은 실제 팀을 운영해보고 실무 자와 관리자, 연구자들 간의 상호 피드백을 교환하면서 변화하는 현실에 맞게 지속적으로 수정, 보완해나가야 할 것이다. 본 연구의 한계점과 향후 과제로 남아있는 점들을 고찰해보면 다음과 같다. 첫째, 본 연구에서는 수시팀과 상시팀 모두에게 적용 가능한 가이 드라인을 개발하는 것을 목표로 하였지만, 실제 DMH-CAT 운영 가이드라인 중 평상시 역할과 업무 및 기능이 상시팀과 수시팀에게 동등하게 적용 가능할 것인지에 대해서는 현장 검증이 필요하다. 또한, 델파이 1 차 설문 이후 재난 인식 개선을 위한 캠페인의 실시, 지역사회 지원봉사자들의 교육이 수시팀에 적절치 못하다는 이유 로 제외되었는데 이러한 활동들은 매우 중요한 준비 활동이라는 점 에서 향후 보완이 필요할 것으로 보인다. 둘째, 본 가이드라인은 미 시적인 관점에서 DMH-CAT 운영지침과 교육 및 훈련에 대한 가이 드라인 중심으로 개발되었고, 거시적인 관점에서 DMH-CAT이 재 난 시 중앙 또는 지방정부와 어떠한 유기적인 관계를 맺고 운영되어 야 할 것인지에 대한 가이드라인은 포함하고 있지 않다. 이는 국내 재난정신건강 위기지원을 어떤 시스템하에서 시행할 것인지에 대 한 모델 구축과 관련되어 있는 문제로 본 연구에서 다루지는 않았 으나 본 가이드라인의 확장 측면에서 향후 보완이 될 필요가 있다.

결론적으로 DMH-CAT 운영 가이드라인이 효율적으로 사용되 기 위해서는 실제 이를 현장에 적용해보고 관련 기관들과 전문가, 실무자 간의 유기적인 상호 피드백 체계를 구축하고, 이를 과학적 으로 검증하는 과정이 지속적으로 이루어져야 할 것이다. 더불어 효율적인 재난위기대응을 위해서는 재난 급성기뿐 아니라 재난발 생 이전의 사전 준비활동과 중장기적인 케어가 요구되는데, 이를 위해서는 각 지역마다 재난위기에 적절히 대응할 수 있는 준비된 정신건강 인력으로 구성된 상시팀을 구축할 수 있는 제도적 장치가 필요하다. 최근 개소한 국가트라우마센터를 중심으로 지역사회 내 
의 전문인력 양성과 함께 재난정신건강 위기대응을 위한 상시팀을 양성할 필요가 있다. 끝으로 DMH-CAT이 합리적인 위기지원 시 스템하에서 운영되고 적절한 교육과 훈련에 의해 팀 효율성을 확보 하기 위한 민관 협력구조 구축 및 다학제적인 노력이 요구된다.

\section{References}

Bisson, J. I., Tavakoly, B., Witteveen, A. B., Ajdukovic, D., Jehel, L., Johansen, V. J., ... Olff, M. (2010). TENTS guidelines: Development of post-disaster psychosocial care guidelines through a Delphi process. The British Journal of Psychiatry, 196, 69-74.

Boulkedid, R., Abdoul, H., Loustau, M., Sibony, O., \& Alberti, C. (2011). Using and reporting the Delphi method for selecting healthcare quality indicators: A systematic review. PLoS ONE, 6, e20476.

Goldmann, E., \& Galea, S. (2014). Mental health consequences of disasters. Annual Review of Public Health, 35, 169-183.

Inter-Agency Standing Committee. (2008). Mental Health and Psychosocial Support: Checklist for Field Use. Geneva: IASC.

James, H. (2007). Psychological first aid. In J. Halpern, \& M. Tramontin (Eds.), Disaster Mental Health: Theory and Practice (pp. 199-223). Belmont, CA: Brooks/Cole.

Linstone, H. A., \& Turoff, M. (1975). The Delphi method: Techniques and applications. Reading, MA: Addison-Wesley.
National Center for Mental Health. (2017). Operating regulations for psychological crisis assistance team at National Center for Mental Health. Seoul, Korea: National Center for Mental Health, Ministry of Health and Welfare.

Neria, Y., Nandi, A., \& Galea, S. (2008). Post-traumatic stress disorder following disasters: A systematic review. Psychological Medicine, 38, 467-480.

North, C. S., \& Pfefferbaum, B. (2013). Mental health response to community disasters: A systematic review. JAMA, 310, 507-518.

Okili, C., \& Pawlowski, S. D. (2004). The Delphi method as a research tool: An example, design considerations and applications. Information \& Management, 42, 15-29.

Suzuki, Y., Fukasawa, M., Nakajuma, S., Narisawa, T., \& Kim, Y. (2012). Development of disaster mental health guidelines through the Delphi process in Japan. International Journal of Mental Health Systems, 6, 7. doi:10.1186/1752-4458-6-7

Workforce Development and Training Program Development Team for Disaster Mental Health Support. (2016). Report on workforce development model. Seoul, Korea: Korea Mental Health Technology R\&D Project, Ministry of Health and Welfare.

Young, M. A. (2009). The community crisis response team training manual (4th ed.). Washington DC: Office for Victims of Crime, US Department of Justice and the National Organization for Victim Assistance.

\section{국문초록}

\section{델파이 절차를 통한 재난정신건강 위기지원팀 운영 가이드라인의 개발

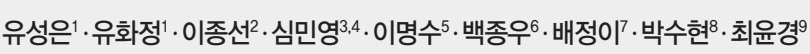 \\ 1충북대학교 심리학과, ${ }^{2 ㄱ ㅏ ㅇ ㅇ ㅝ ㄴ ㄷ ㅐ ㅎ ㅏ ㄱ ㄱ ㅛ ~ ㅅ ㅣ ㅁ ㄹ ㅣ ㅎ ㅏ ㄱ ㄱ ㅘ, ~}{ }^{3}$ 국립정신건강센터 불안스트레스과, ${ }^{4}$ 국립정신건강센터 국가트라우마센터, ${ }^{5}$ 용인정신병원, ${ }^{6}$ 경희대학교 의과대학 정신건강의학과, ${ }^{7}$ 인제대학교 간호학과, ${ }^{8}$ 연세대학교 심리학과, ${ }^{9}$ 계명대학교 심리학과}

'재난정신건강 위기지원'은 재난생존자와 지역사회의 심리사회적 회복을 도모하기 위한 일련의 활동을 의미한다. 재난 발생 시 정신건강 위 기지원은 개인 차원이 아닌 팀 차원으로 제공되므로 지역사회에 이를 수행하는 훈련된 팀을 양성하는 것이 중요하다. 하지만 국내 현실에 맞게 재난정신건강 위기지원팀을 어떻게 양성하고 교육, 훈련시킬 것인지에 대한 전문가들의 합치된 의견에 대한 검증은 부족하다. 본 연구 는 델파이 절차를 사용하여 재난정신건강 위기지원팀(DMH-CAT)의 운영 가이드라인을 개발하는 것을 목적으로 하였다. 본 연구에서는 전문가 패널을 통해 초기문항을 구성하였고, 이에 대한 전문가들의 합치된 의견을 알아보기 위해 초기문항 구성을 위한 전문가 패널에 참 여하지 않은 재난정신건강 분야 전문가들을 대상으로 2 회기의 구조화된 온라인 설문을 실시하였다. 이러한 과정을 거쳐, 총 13 개의 세부영 역에서 84개의 가이드라인이 개발되었다. 가이드라인 세부 영역으로는 용어의 정의, 미션과 목표, 구성, 팀, 팀 리더, 팀원의 역할 및 기능(평 상시와 재난·위기 발생 시), 팀 역량 및 운영체계에 대한 평가, 교육과 훈련, 팀 케어 및 소진예방, 윤리가 포함되었다. 최종 문항에 대한 전문 가 동의 평정 평균은 1-9점 척도에서 8.20으로 전반적으로 높게 나타났다. 본 연구에서 개발한 DMH-CAT 운영 가이드라인은 가능한 일반 적인 원칙들을 기술하는 항목들로 구성되어 있어 재난정신건강 위기지원을 위한 다양한 형태의 팀에서 활용할 수 있을 것으로 기대한다.

주요어: $\mathrm{DMH}-\mathrm{CAT}$, 재난정신건강, 위기지원팀, 가이드라인, 델파이 